\section{Medical profession to investigate torture}

"TORTURE should become a field of scientific research, to include forensic study, the training of torturers, the detection of torture marks, and, ultimately, the provision of improved medical care for torture victims."

Such was the startling conclusion of more than 100 doctors from Europe and North and South America, attending a seminar on "Violations of human rights: torture and the medical profession," held in Athens on 10-11 March. The doctors see the results and incidence of torture as "a traumatic disease -.-inflicted by humans on humansthat should be investigated and publicised by the medical profession."

This "disease", although endemic in human society, has of recent years reached almost epidemic proportions, while there are an increasing number of allegations of the involvement of doctors in such practices, either by using their knowledge to design and "improve" torture techniques, or by acting as observers, to ensure that the victim does not succumb prematurely. This has caused considerable alarm within the medical profession, and there have been several small meetings to discuss what action the profession as a whole should take. The Athens seminar was the first major gathering.

In addition to advocating research into the sociological and psychological factors involved in the problem of torture, the assembled doctors recommended that governments and intergovernmental organisations, especially the UN, should consider new means of helping torture victims, and also that an international convention should be drafted, which would clarify the responsibility of the state for the financial compensation and rehabilitation of torture victims. (At present, many victims are unable to claim any aid, on the grounds that the present regime was not responsible.)

The doctors' stand is seen by human rights campaigners as analogous to that of the psychiatrists against the political misuse of psychiatry for political repression-a campaign which culminated in the resolution of the World Psychiatric Association (Honolulu, 1977) censuring the psychiatric repression of dissidents in the Soviet Union. This campaign, of course, is by no means over-although the latest reports from Moscow indicate that the censure motion has caused a gallant handful of Soviet psychiatrists to opt out of such political "treatments". At least seven are known to be suffering reprisals for this refusal, two of whom, Drs Olga Viktorovna Makarova and Anatolii Nikitich Barabanov have been arrested. According to one report, Dr Barabanov has now himself been declared mentally ill and is undergoing compulsory "treatment" in a penal psychiatric hospital.

Vera Rich

\title{
More Comecon cosmonauts
}

Following the successful and recordbreaking mission of Salyut-6/Soyuz-26/ 27-28, plans are now firmly underway for the next two Comecon cosmonauts each with a Russian companion, to go into orbit "before the end of the year". According to Aleksei Leonov, Deputy Head of the Soviet Space Training Centre, they will be a Pole, then an Hast German. Representatives of all the other Comecon countries (including Cuba and Mongolia) have now arrived at the Gagarin Space Centre, to begin training for the flights that "before 1983" will further proclaim the ideal of socialist cooperation in space.

The scientific, as opposed to the symbolic, value of such participation will clearly vary from country to country. Cuba and Mongolia, for example, contribute to the Comecon "Interkosmos" programme mainly by providing tracking facilities. It is unlikely that they will contribute much new science. Czechoslovakia, however, made considerable contribution scientifically.

Czechoslovak microbiologists provided special Chlorella strains, including mutations deprived of chlorophyll. Although Chlorella experiments had been carried out on Salyut-4 and at an earlier stage of the Salyut-6 mission, access to the "unique collection" of strains produced in Czechoslovakia made a considerable difference. For the first time, active growth was observed. In the past, the growth has been retarded in space conditions.

Czechoslovakia also provided an oxymeter, for monitoring the effect of weightlessness on oxygen in human tissue. In deference to Czech national sentiments, the press releases stressed that this was based on Heyrovsky's principle of polarography. Similarly, the Czech capsule 'Morava', was used with the Soviet 'Splav-Ol' furnace. The "Splav" experiments are concerned with production of homogeneous alloys of substances with greatly differing atomic weights, which would be impossible under conditions of gravity. They also study the mechanism of crystallisation and vitrification in weightlessness. 'The 'Morava' experiment extended these investigations to some electro-optical materials.

A joint experiment, with the somewhat gloomy name of 'Hkstinktsiya' studied changes in the brightness of stars setting below the earth's horizon to obtain experimental data on the presence of a layer of micrometeorite dust at a height of $80-100 \mathrm{~km}$. The joint Soviet-Czechoslovak experiments were largely carried out by Remek and Gubarev his partner from Soyuz-28.

Since Salyut-6 is built to a "compartment" design, the two crews can operate independently, without seeing each other for hours on end. It is claimed that, if necessary, Salyut-6 could hold up to six people, without their getting in each other's way. Nevertheless, considerable attention is being paid to psychological stress among the crews of space stations. According to $\mathrm{Dr}$ Odlrich Miksik of the Czechoslovak Psychiatric Research Institute, it is necessary to study how "the feeling of responsibility, time-frustration, and so on, influence decision-making in extreme situations". In the future, he said, it might be possible "to predict the crew's responses... and to intervene, to make the responses as efficient as possible". This rather alarming suggestion of psychotherapy in space possibly means no more than providing sufficient rest and variety of occupation during long-term missions and of eliminating latent causes of friction. Part of the current psychological "experiment" included a special "subjective testing" scale, the "Supos-8". Work on this system began in 1967. In a Soviet experiment in 1975-6 a group of Komsomols trekked over the ice to Jan Mayen Land, recording their interpersonal relations throughout. According to Dr Miksik, the analogous Czech experiment was carried out several years earlier, using mountaineers in the Hindu Kush.

Vera Rich

\section{Soviet scientists petition Carter}

ThIRTY-ONE prominent Soviet scientists have sent a letter to President Carter, calling on him to "rise above transient considerations" and renounce production of the neutron bomb. The bomb, they said, would not consolidate the power and security of the USA, because history showed that no country had yet succeeded in retaining for long the monopoly of possession of any particular weapon of mass destruction.

Signatories of the letter include Academician Anatolii P. Aleksandrov, President of the Academy of Sciences of the USSR, and the Nobel Prizewinners, Academicians N. G. Basov, L. V. Kantorovich, A. M. Prokhorov, N. N. Semenov, and P. A. Cherenkov. 